Canadian University Music Review

Revue de musique des universités canadiennes

\title{
Stephen Blum, Philip V. Bohlman, and Daniel M. Nueman, eds. Ethnomusicology and Modern Music History. Urbana: \\ University of Illinois Press, 1991. 322 pp. ISBN 0-252-01738-2
}

\section{Gordon E. Smith}

Numéro 13, 1993

URI : https://id.erudit.org/iderudit/1014303ar

DOI : https://doi.org/10.7202/1014303ar

Aller au sommaire du numéro

Éditeur(s)

Canadian University Music Society / Société de musique des universités canadiennes

ISSN

0710-0353 (imprimé)

2291-2436 (numérique)

Découvrir la revue

Citer ce compte rendu

Smith, G. E. (1993). Compte rendu de [Stephen Blum, Philip V. Bohlman, and Daniel M. Nueman, eds. Ethnomusicology and Modern Music History. Urbana: University of Illinois Press, 1991. 322 pp. ISBN 0-252-01738-2]. Canadian

University Music Review / Revue de musique des universités canadiennes, (13), 156-160. https://doi.org/10.7202/1014303ar

All Rights Reserved (c Canadian University Music Society / Société de musique des universités canadiennes, 1993
Ce document est protégé par la loi sur le droit d'auteur. L’utilisation des services d'Érudit (y compris la reproduction) est assujettie à sa politique d'utilisation que vous pouvez consulter en ligne.

https://apropos.erudit.org/fr/usagers/politique-dutilisation/ 
Qureshi defends her "operational choice" of analysing qawwali music from the vantage-point of the qawwal on the grounds that he was ultimately "the exclusive maker of the music" (p. 230). This position, moreover, offers her "a key to dealing with the music-context relationship in an analytically clean" (p. 230) and "holistic" (p. xiv) manner. But can the religious experience of qawwali music be apprehended cleanly, holistically, and from a vantage-point that is paradigmatically more socio-economic than spiritual? The qawwal may be the designated spokesperson for the qawwali assembly, yet he is, by function, by social reality, and by Sufi ideology still largely excluded from the full Sufi experience of mystical love and divine ecstasy.

Qureshi acknowledges that her approach offers only one of potentially numerous views on the subject of qawwali:

There still remains the more fundamental question of whether any single vantage point can generate knowledge that is more than a point of view, predicated on the expectations that originate with that vantage point; whether indeed the knowledge of a musical event - or any event - must not be derived from a view in the round; whether such a view is epistemologically possible; and most important, whether the dynamic behind human action, even that of one individual, can be grasped across cultural, social and intellectual boundaries that remain real in practice just as they may be accounted for analytically (p. 230).

One would be hard-pressed to contest this superbly documented study on empirical grounds. Sufi Music is an engaging read for those interested in understanding not just qawwali, but also how music - perhaps all musics - is informed by, shaped by, and interacts with the ideological, socio-economic, and performance environments of its composers and performers.

Kenneth Chen

Stephen Blum, Philip V. Bohlman, and Daniel M. Nueman, eds. Ethnomusicology and Modern Music History. Urbana: University of Illinois Press, 1991. 322 pp. ISBN 0-252-01738-2.

This volume of fifteen essays is dedicated to the American ethnomusicologist, Bruno Nettl, on the occasion of his sixtieth birthday. Nettl's international prominence as a music scholar is well-known and recognized. He is a prolific author whose writings include numerous books and articles on a range of research areas: the music of the Middle East (Iran), North American native 
music, European and American folk music, and more general interests such as acculturation and modernization in traditional music. Nettl's influence as a teacher is equally important; he has instructed, inspired, and guided an impressive number of students who have subsequently distinguished themselves by significant contributions to the discipline of ethnomusicology. Many of the authors represented in Ethnomusicology and Modern Music History are former students of Nettl, and, as Stephen Blum comments at the end of the prologue, all present their work as appreciation of Nettl's pioneering scholarship and friendly counsel.

Most notable about the collection is that it represents vital new emphases in ethnomusicology, particularly the critical value of history and historical consciousness as viewed through specific musical events, and the continuing emergence of reflexive enquiry as a critical process and a broadening force in the discipline. The essays are grouped into four parts: Music and the Experience of History, Authority and Interpretation, Brokers and Mediators, and Musical Reproduction and Renewal. In the prologue, Blum examines the global notion of "modern music history" as a subject of scholarly enquiry. By extending the enquiry beyond European worldviews including those represented in the first "general histories of music" from the mid-eighteenth century, Blum articulates a stance which takes into account not simply "non-Western" areas, but the following notion: "According to the conceptions that inhabitants of each region have formed of their own histories, modern music history extends over different periods of time in various parts of the world" (p. 4).

The first four essays in the collection present different contexts within which their authors consider ways music intersects with the experience of history. As Anthony Seeger observes in the opening essay, the Suyá Indians of central Brazil construct and reproduce history in song. The appropriation of "foreign" songs through encounters with many peoples is a base for Suyá history and a source of restructuring of Suyá myth. The essays by David Copland and Christopher Waterman are studies of two modern African genres - Sotho "lifela" and Yoruba "jùjú." The authors show how performers of both genres reproduce and, indeed, create mythic structures as they interpret historic events. Waterman, for example, challenges the "core concept" of tradition to ethnology, folklore, and ethnomusicology, and suggests that there is a contradiction which "revolves around the necessarily social and historical origins of tradition, in opposition to its status in both native and scholarly discourse as something immutable, a structure of historical culture fundamentally immune to history" (p. 36). Within the specific context of the 1932 Congress of Arab music held in Cairo, Ali Jihad Racy outlines two incompatible attitudes toward history and the misinterpretation of specific terms such as "Occidental" for "new" and "Oriental" for "old." 
This article is a penetrating account of racial misrepresentation triggered by Western bias.

In the second part of the book, Charles Capwell examines controversies surrounding certain North Indian "gharanas" or lineages (disciples and students) of musicians. (This subject is also discussed in Stephen Slawek's essay on Ravi Shankar later in the book.) Capwell highlights the importance of stories in the transmission of musical knowledge in North Indian music culture; he also recounts the origin myth of the Visnupur gharana, arguing that stories which describe the transfer of specialized knowledge from the Aryan heartland to Bengal legitimize such a Bengali institution as the Visnupur gharana. In her essay, Regula Qureshi analyzes the performing tradition ("qawwali") and discusses the hereditary musicians ("qawwals") which are part of Sufi religious tradition; she focuses on the local tradition and repertory of a specific group of "qawwal" performers from Dehli, thereby introducing a discussion of the issue of historicity in oral tradition. Thomas Turino's essay on three different interpretations of a Peruvian panpipe style and that of William Noll, "Music Institutions and National Consciousness among Polish and Ukrainian Peasants," both deal with the reinterpretation of rural musical practice and the issue of hegemony in their respective contexts.

In the third part, "Brokers and Mediators", the authors examine the achievements of individuals whose work has served to create cultural and historical links. Ravi Shankar is viewed by Stephen M. Slawek as an exemplary mediator "who has excelled as both a traditional performer of Hindustani music and an innovative artist with an international career" (p. 14). In his reassessment of Michel Fonton's Essai sur la musique comparée à la musique européenne, Amnon Shiloah emphasizes the originality of the eighteenth-century French scholar's work in its historic context; Shiloah also observes the existence of marked parallels between Fonton's ideas and some of the major concerns of modern ethnomusicology. Through the examination of a collection of Louisiana Indian songs, Victoria Lindsay Levine focuses on the music-culture of the late Choctaw woman, Arzelie Langley. Levine studies the phenomenon of pantribalism which existed in parts of Louisiana and east Texas. It is now "a lost tradition," but Levine concludes that its very existence at one time provides further documentation for the Southeast as a musical area. In her essay on the history of interaction between the Mundas and other tribes and castes in northeastern Central India, Carol Barbiracki identifies different kinds of mediators, such as "the mendicants whose devotional songs have found greater acceptance among Mundas than their religious message" (p. 15), or the caste musicians who have served tribal as well as caste patrons. In various ways, the theme of brokers and mediators in these (and other) essays in the volume reaffirms the continuing 
importance of "new" and "old," and "inside" and "outside," as core issues in ethnomusicological discourse.

In the fourth part of the book, the theme of musical reproduction and renewal is examined by three authors. Helen Myers discusses the modern music history of Felicity, Trinidad, against the backdrop of its South Asian roots. She argues that musical reproduction and renewal within the context of this small East Indian community illustrates certain fundamental issues of ethnomusicology, such as "the deliberateness of musical change," and that the "musical grey-out" phenomenon, or the universal Westernization of the world's music, is not so pervasive as many ethnomusicologists used to fear: "Musical change is moving in directions we did not anticipate" (p. 241). In his study of an old (1909) and a new (1968) recording of what "etically" appear to be the same Blackfoot song, Robert Witmer presents a very different context of musical reproduction. Witmer challenges his own transcriptions against processes of oral tradition and concludes with further suggestions for computer-assisted investigations of Blackfoot recordings.

The book's final essay by Philip V. Bohlman deals with ethnomusicological meaning in Western music history through the examination of chamber music within the framework of Central European Jewish society. A former student of Nettl's at the University of Illinois, ${ }^{1}$ Bohlman identifies and interprets some of the most important themes in his teacher's recent work. Implicit in Bohlman's work is the contention that the history of Western art music, including styles, genres, and social contexts, "lends itself to ethnomusicological approaches" ( $p$. 266). His final statement, “... it may be that the truly diverse and complex levels of meaning in music history can only be explored fully when viewing music and history from the abundant perspectives that ethnomusicology not only tolerates, but encourages" (p. 267), reflects one of the strongest Nettl-inspired views in the discipline today. In his "epilogue," Daniel E. Neuman continues this theme by recapitulating the book's essays from the perspective of "paradigms and stories" in contemporary ethnomusicological discourse. Neuman's argument, “... that history is less important for the telling of it as such, than for the meanings that can be construed for its participants" (p. 276), reinforces the position held by many in the discipline of ethnomusicology that there are inextricable connec-

1 Bohlman also co-edited with Nettl a recent collection of essays dedicated to the late Alan P. Merriam, Comparative Musicology and Anthropology of Music: Essays on the History of Ethnomusicology, Chicago Studies in Ethnomusicology (Chicago: University of Chicago Press, 1991). In its aim to identify perspectives and paradigms, historic and current in the discipline, this book serves as a valuable companion volume to Ethnomusicology and Modern Music History; combined with other recent literature and public debate, these volumes are part of the emerging concern with new cross-cultural emphases and inter-disciplinary directions in ethnomusicology. 
tions between the "stories" ethnomusicological enquiry tells and other domains of human subjects.

By virtue of the compelling and broad-reaching ways in which historical consciousness and reflexive enquiry in ethnomusicology are revealed in its essays, Ethnomusicology and Modern Music History should be of interest not only to ethnomusicologists, but also to musicologists, anthropologists, and historians as well. Indeed, the book is a most fitting tribute to one of the great contributors and inspiring scholars in the discipline of ethnomusicology.

Gordon E. Smith

Nicole Labelle. Catalogue raisonné de l' œuvre d'Albert Roussel. Publications d'histoire de l'art et d'archéologie de l'Université catholique de Louvain, $\mathrm{n}^{0} 78$. Louvain-la-Neuve: Université catholique de Louvain, 1992, 159 pp.

Les œuvres d'Albert Roussel (1869-1937) sont longtemps restées dans l'ombre de celles de certains de ses contemporains tels que Dukas, Ravel ou Debussy. Pourtant, Padmâvatî, Bacchus et Ariane, les Troisième et Quatrième symphonies, pour n'en citer que quelques-unes, ont connu un immense succès lors de leur création. Oubliées au lendemain de la Seconde Guerre mondiale, ces œuvres semblent reprendre leur place dans l'histoire de la musique. Depuis une dizaine d'années, l'importance de ces compositions dans l'évolution de la musique française de la première moitié du $\mathrm{XX}^{\mathrm{e}}$ siècle ne fait plus de doute. Outre de nombreux enregistrements, il existe plusieurs publications récentes sur Roussel. Trois d'entre elles ont été publiées en 1987, année du $50^{\circ}$ anniversaire de sa mort: (1) un collectif réunissant des articles et un catalogue, publié par l'École Normale de Musique de Paris'; (2) un Catalogue chronologique de l' auvre d'Albert Roussel (Actes du colloque international Albert Roussel); et (3) un ouvrage intitulé Lettres et écrits d'Albert Roussel ${ }^{2}$ édité par Nicole Labelle, qui est actuellement reconnue comme l'une des spécialistes de ce compositeur. Elle vient de compléter ce travail par un Catalogue raisonné de l'œuvre d'Albert Roussel, publié dans la collection « Publications d'histoire del'art et d'archéologie de l'Université catholique de Louvain ", qui comprend une dizaine d'ouvrages consacrés à la musicologie.

1 Voir plus particulièrement Nicole Labelle, «Images de sa vie », dans Albert Roussel, édité par l’École Normale de Musique (Paris: Actes Sud-Papiers, 1987), 9-23.

2 Albert Roussel, Lettres et écrits d'Albert Roussel, textes réunis, présentés et annotés par Nicole Labelle (Paris: Flammarion, coll. « Harmoniques », 1987). 